Journal of Patient-Centered

7-29-2019

\title{
A Letter to My Departed Niece
}

*Anonymous *

Follow this and additional works at: https://aah.org/jpcrr

Part of the Behavioral Medicine Commons, Community Health and Preventive Medicine Commons, Medical Humanities Commons, Mental and Social Health Commons, Mental Disorders Commons, and the Public Health Education and Promotion Commons

\section{Recommended Citation}

Anonymous. A letter to my departed niece. J Patient Cent Res Rev. 2019;6:216-7. doi: 10.17294/ 2330-0698.1703

Published quarterly by Midwest-based health system Advocate Aurora Health and indexed in PubMed Central, the Journal of Patient-Centered Research and Reviews (JPCRR) is an open access, peer-reviewed medical journal focused on disseminating scholarly works devoted to improving patient-centered care practices, health outcomes, and the patient experience. 


\title{
A Letter to My Departed Niece
}

\author{
Anonymous*
}

I was attending a conference on physician burnout and well-being when I learned that my 15 -year-old niece had died. For those of us unaware of her diagnosis until recently, it felt like the battle was over just as it had begun. The finality of death was crushing - my legs gave out twice on the short walk back to my room - a grown man on the ground with swollen tearful eyes formed a stark contrast to the resort patrons dressed in robes strolling between spa appointments.

Hours of inspiration and self-reflection on how to conquer call, my email, and the EHR to become a better husband and father, as well as to role-model wellness for my residents, seemed to be erased in the instant I learned she was gone. The days that followed were filled with an intense desire to be surrounded by close friends and family, but of course, we inevitably all needed to return to our home towns and routines, left with precious memories and old photos of B to comfort us.

I have found myself staring at my parents' Christmas card from 2 years ago. My mom is a fan of those classic synchronized outfits that make those "Awkward Family Photos" books possible. She usually mandates that we wear all white or blue, but that year was different. We were all wearing green shirts with big yellow ribbon logos in the front. B is smiling in the back row with her classic dark-rimmed glasses. Our shared severe myopia and introverted nature created a running family joke that the storks mixed up their deliveries between my brother and me. She excelled in violin and had a passion for literature. Her teachers said she was one of the best writers that they had ever taught.

*Name withheld to maintain confidentiality.

Correspondence: JPCRR Editorial Office, 960 N. 12th Street, \#411, Milwaukee, WI 53233 (JPCRR@aurora.org)
But while B's "light up a room smile" centers this photo perfectly, she wasn't the one we were wearing those pediatric cancer T-shirts for - that was my nephew T. When he was diagnosed with a rare form of cancer, my sister's family, community, and friend network sprang into action, helping him and their family in whatever they needed and raising money for cancer research through wristbands, T-shirts, and an incredible fundraiser thrown by her childhood friends. We all shared his terrible diagnosis and his story with co-workers - my residency coordinators wanted as much information as I was willing to share so that they could make their prayers as detailed as possible. This incredible outpouring of support not only facilitated my sister's family through T's treatment and on to "cancer free" status, but it left the rest of us in awe of the human capacity for love and generosity.

B's course was quite the disparity. While she also suffered from a horrendous disease, in contrast to my nephew and even after her passing, I have found myself sharing very few details of her death. Beyond those whom I thought absolutely needed to know, I have simply told everyone that my absence from work was due to "a death in the family."

I find myself struggling with why I am so hesitant to share the details of my niece's death. My initial reasoning was based on my understanding of emotional intelligence. Every person that I shared this information with was an emotional wreck after they had heard. To empathically place yourself in my brother's shoes ... your teenage daughter does not respond to a text message, so you head home early to check on her and find her pulseless in her bedroom. You call the ambulance and initiate CPR, but it's too late. She's not coming back ... it simply feels like too much for the human mind to handle. I can still barely type the words out. 
The more time passes, the more a secondary guilt has grown - the one that follows the initial guilt of wishing you had done something, be it large or small, that might have eased her suffering or even prevented her death. This secondary guilt is more of a cognitive dissonance. I have deeply held beliefs that I'm clearly not standing by in my current actions. I worked in a mental health clinic for 8 years. I've tried to fight the mental health stigma in interactions with patients, medical students, and residents throughout my entire career. Why is mental health different? Why is it that someone might say "I'm sure you will feel better soon" to a patient with depression, yet never say that to one with cancer? And why am I not able to tell everyone about my niece's illness and my family's experience? "Too private?" Or is it simply "too stigmatized?"

How do we invite those around us in, to welcome the connections that we need to get through tragic loss, when we have been conditioned to share the minimum and leave ourselves isolated? Feeling connected is not specific to physicians achieving well-being. I share the following letter to my departed niece to, hopefully, allow others a chance to feel that connection.

\section{Dear B,}

While we all mourn losing you, we find solace in knowing that your suffering has ended.

Your funeral was beautiful. There were amazing photos from childhood through your early teens streaming overhead, even some from your family's recent trip to Maui. After your orchestra finished "See You Again," there wasn't a dry eye in the house. Your school friends and your younger sister filled us in on the parts of your life many of us didn't know about in their powerful and well-written speeches. I will always cherish having heard them. We always knew you as shy, preferring the company of books up in your room over a seat at the table on our loud family vacations. They knew you as a wonderful and devoted friend, who was always willing to give more to others than you kept for yourself.

You died from a disease as serious as cancer, but one that most of us struggle to talk about. You died of Suicide, a complication of your severe Anxiety and Depression. May we all have the courage to heed your pastor's final words at the service - to say their names, to call them out from behind closed doors where they ravage the minds and souls of so many in complete silence.

Maybe then we'll be better at helping kids like you beat them.

Love,

Uncle Will

The author thanks all of those who work in suicide prevention and notes the following important resources: National Suicide Prevention Lifeline: 1-800-273-8255; National Alliance on Mental IIIness (NAMI) HelpLine: 1-800-950-6264. 